\title{
Fine in the System of Punishments for Crimes against Property and Some Issues Related to the Enhancement of Its Effectiveness
}

\author{
IRINA V. AZAROVA
}

Voronezh Institute of the Ministry of Internal Affairs of the Russian Federation, Voronezh, Russian Federation

ORCID: 0000-0003-3497-2126, e-mail: aziravlad@rambler.ru

\section{IVAN V. DVORYANSKOV}

Research Institute of the Federal Penitentiary Service of Russia, Moscow, Russian Federation

ORCID: 0000-0003-0542-5254, e-mail: diw@yandex.ru

A bstract. The article analyzes the place and role of fines in the system of criminal penalties and looks into some trends in its establishing by the legislator and application by the court. We investigate property protection issues that have always been in the focus of attention of legislators and legal science and that have never lost their relevance, because they relate to the inviolable vital interests of an individual, society and the state. In the framework of the topic under consideration, we undertake to explain our viewpoint on three basic terms: "fine", "property" and "punishment effectiveness". We conclude that property should be considered (among other things in the establishment of the elements of a crime) as a complex multifaceted phenomenon associated with ensuring the security of individuals, society and the state from various threats, including those of an intangible nature. We analyze fine as a penalty and fine imposed by the court as a criminal law measure in the aspect of legal regulation and application practice. We carry out comparative analysis of the rules on the protection of property and the application of penalties in the form of a fine for encroachment upon it on the example of the criminal legislation of the Republic of Belarus. 
As a result, we conclude that the importance of fine in the structure of penal sanctions is increasing; we note that there is a trend to increase the use of a court imposed fine as an exemption from penal sanctions. At the same time, we point out that this approach used by legal professionals does not fully fit in with the legally established principle of social justice as the goal of punishment. Crimes against property should be considered as a threat not only to property, but also to the life and health of people (Article 162 of the Criminal Code of the Russian Federation), moral, spiritual and other values of an individual and society. We believe this approach should be used both in legislative and law enforcement practice, including cases of applying a court imposed fine.

Key words: property; fine; court imposed fine; punishment goals; punishment effectiveness.

12.00.08 - Criminal law and criminology; penal law.

F or c it ation: Azarova I.V., Dvoryanskov I.V. Fine in the system of punishments for crimes against property and some issues related to the enhancement of its effectiveness. Penitentiary Science, 2020, vol. 14, no. 4 (52), pp. 551-555. DOI 10.46741/2686-97642020-14-4-551-555.

Property protection issues have always been the focus of attention of the legislator and legal science, and they have never lost their relevance because they deal with inviolable vital interests of an individual, society and the state. The legislator also recognizes them as such, having defined in the fundamentals of the constitutional system the provision that private, state, municipal and other forms of property are recognized and equally protected in our country (Article 8 of the Constitution of the Russian Federation). At the same time, the Constitution stipulates that no one "may be deprived of their property except by a court decision" (Part 3, Article 35). Compulsory acquisition of property is allowed only on condition of preliminary and equivalent compensation for it.

Property protection is carried out in various ways, including criminal legal means [9, p. 118138]. It is known that traditionally the structure of crime is dominated by theft [4, p. 461]. Suffice it to say that in 2019, according to official data from the Prosecutor General's office of the Russian Federation, they accounted for $42.5 \%$ of the total number of all registered crimes. The share of those convicted of crimes under Chapter 21 of the Criminal Code of the Russian Federation in 2019 reached $37.4 \%$ [7]. The indicators of the court-imposed fine for the analyzed Chapter were even higher: out of 33,329 such fines, $46.3 \%$ were imposed under the articles of this part of the criminal law.

However, the scientific elaboration of the topic of fine and the level of generalization of its application in the context of the effectiveness of this type of punishment do not correspond to its significance.

The development of the topic under consideration urges us to clarify our position on its three basic notions, which are "fine", "property" and "punishment effectiveness", all of them are in the center of ongoing debate in legal science.
It is known that the notion of "fine" [shtraf in Russian - translator's note] is of German origin, it comes from the word "die Strafe", which means punishment in Russian [11, p. 521]. The current legislation uses this definition very widely in the leading branches of private and public law.

Thus, the Civil Code of the Russian Federation recognizes the forfeit (the fine, the penalty) as the sum of money, defined by the law or by the agreement, which the debtor is obliged to pay to the creditor in case of his non-discharge, or an improper discharge, of the obligation (Article 330 of the RF Civil Code).

The Code of Administrative Offences of the Russian Federation defines fine as a monetary sanction expressed in terms of rubles or at a multiple of various indicators, including a multiple of the cost of the administrative offense or the amount of unpaid taxes, or taxes payable, and so on (Article 3.5 of the RF Code of Administrative Offences).

According to the Criminal Code of the Russian Federation, a fine is a monetary penalty imposed within the limits provided for by the Criminal Code (Article 46 of the RF Criminal Code).

Analysis of the legal and doctrinal interpretation of this phenomenon allows us to conclude that a fine is a measure of material impact on the offender implemented so as to compensate for material damage, moral damage, and also for the implementation of multi-faceted socially significant goals of punishment.

As for the notion of "property", it is traditionally basically a category of civil law, the essence of which is expressed in the ability of any person to legally have an unlimited amount of property, own, use and dispose of it freely. The use of this definition in other branches of law is the subject of ongoing disputes.

Thus, there is an opinion that the condition of both the Russian criminal legislation and the 
established criminal law theory on the issue of the connection of the definition of property with the essence of criminal law is unsatisfactory [2, p. 4]. Having pointed outa certain categorical implication of the statement we note that it is not entirely justified, and we would like to add that at the end of the past century the analysis of global changes in the country's socio-economic and political nature shows that criminal law science has developed an opinion according to which such features as "materiality", "economic value" and "price" are not always crucial in determining property as an object of encroachment. Moreover, the author of the reasoning provided above indicates that different chapters of the Criminal Code contain components representing property as private area (Item B, Part 2, Item A Part 3 of Article 58), and the basis for social existence (Articles 167,168, 214), etc.

At the same time, we agree with the conclusion that property should be considered (among other things, in cases when the elements of a crime are determined) as a complex multi-faceted phenomenon [1, p. 22] associated with ensuring the state of protection of an individual, society and the state as the main security objects from various threats, including non-material ones (life and health, spiritual and moral values, etc.) [10, p. 313].

Eight types of penalties out of thirteen provided for in the RF Criminal Code are applied as basic and additional punishments for encroachments upon one's property. Fine can be applied as the main or additional penalty from the total amount of such sanctions.

For comparison, in the Criminal Code of the Republic of Belarus, with which our country forms the Union State, and we may assume that in the framework of integrative legal thinking that we recognize [3, p. 57-63], the legislation in different spheres of public life will be leveled off, and the number and types of penalties for encroachment upon one's property match by about $70 \%$. At the same time, the Criminal Code of the Republic of Belarus contains no such penalty as "compulsory labor". We should note that this sanction is used as an alternative to incarceration in cases explicitly provided for in the Criminal Code and implies putting the convicted to labor in places determined by the institutions and bodies of the penal system, followed by deduction from 5 to $20 \%$ of the wage of the convicted person's income for the benefit of the state. This type of punishment in our country was introduced by Federal Law 420-FZ dated December 7, 2011 and is applied only from January 1, 2017, not being particularly popular with executors of law. Thus, in 2018 on the whole this sanction was applied to 1,030 individuals, although it is twice as big as in 2017.

Unlike the Belarusian criminal law, the Criminal Code of the Russian Federation does not have such a penalty as "community service". In accordance with Article 49 in Belarus, such a sanction provides for a convicted person to engage in unpaid labor for a period of 60 to 240 hours for the benefit of society, and the type of such labor is determined by the authorities responsible for the implementation of community service.

In addition, as we look into the features of the Criminal Code of the Republic of Belarus in the area under consideration, we should recognize that it is justified that Belarus, compared to Russia, uses on a wider basis such penalty as deprivation of the right to hold certain posts or to be engaged in a certain activity for encroachment upon one's property. We believe that in our country, given the level of corruption, which in 2008 the President of the Russian Federation called Number One enemy of a free, democratic and just society, it is appropriate in all cases, in which officials may be involved in embezzlement, to provide for this type of criminal penalty as an alternative to other penalties, including a fine.

Our attitude toward diversity and mix of different types of punishments is sooner positive than negative, because it enables law enforcement officials to consider specific features of the elements of a crime, personality of the offender, as well as doctrinal and legal achievement of the purposes of punishment, its social effectiveness [8]. In this context, according to the Criminal Code of the Russian Federation, a fine is a special type of punishment, used in various ways: a) as the main type of penalty; as an additional type of penalty; as another criminal law measure (court imposed fine). In general, fine ranks third among the penalties for encroachment on property and goes after incarceration and compulsory labor. Thus, in 2019 fines were imposed as the main ones on 20,800 convicts for crimes against property, which is approximately $8.9 \%$ of the total number of persons convicted under Chapter 21 of the RF Criminal Code $(228,953)$.

The law establishes a fine in certain amounts defined in specific elements of criminal offences (Article 46 of the RF Criminal Code). At that, its lower limit is set at five thousand rubles and the upper limit at five million rubles. In parallel with the establishment of a fine in absolute totals, it is estimated: a) in the amount of the wage or salary or any other income of the convicted person for a period from two weeks to five years; b) in the amount which is a multiple of the cost 
of the article, or of the sum of commercial subornation or bribe; c) in the amount of the bribe or the amount of illegally moved funds and (or) the value of monetary instruments.

The Criminal Code of the Russian Federation makes an exception from the established amounts of minimum and maximum fines for a fine related to commercial bribery, bribery of a contract service employee, contract manager, member of the procurement commission and other authorized persons representing the interests of the customer in the procurement of goods, works, services for state or municipal needs, as well as a bribe or the amount of illegally moved funds and (or) the cost of monetary instruments. The penalty in the form of a fine for the commission of such crimes may not be less than twenty-five thousand rubles and not more than five hundred million rubles.

At the same time, the legislator obliges the court to take into account the gravity of the crime committed and the property status of the convicted person and their family when imposing a penalty. The opportunities to receive a wage, salary or other income by the convicted person should also be clarified. Taking into account the same circumstances, the court may impose a fine with installment payments in certain parts for a period of up to five years.

In case of malicious evasion of payment of a fine imposed as the main penalty it is replaced by any other penalty among those contained in the RF Criminal Code, with the exception of deprivation of liberty. The exception to this rule is a fine that is estimated as a multiple of the cost of the article or of the sum of commercial subornation or bribe and that is replaced by a punishment within the sanction provided for in the relevant article of the Special Part of the criminal law. At that, the sentence imposed cannot be suspended.

A fine as an additional type of punishment can be imposed only in cases provided for in the relevant articles of the Special Part of the RF Criminal Code. Their analysis under Chapter 21 of the criminal law shows that in cases where a fine is not the main type of punishment, it is established as an additional one (Articles 161, 162, 163, 164).

A court imposed fine as a type of exemption from criminal liability for a petty or medium-gravity crime committed for the first time was introduced in Chapter 11 of the RF Criminal Code in 2016 by Federal Law 323-FZ. The court can make such a decision if the person who committed a crime has compensated for the damage inflicted or has in any other way effected restitution for the damage caused as a result of the crime. The dynamics of applying a court imposed fine over the past two years are characterized by the following indicators. In 2019 26,040 people were exempted from criminal liability under Article 76.2 of the RF Criminal Code; this figure is by 10,588 people or $41 \%$ more than in 2018. At the same time, the vast majority of persons released on such grounds in 2019 (12,850 people) fall under Parts 2 and 3 of Article 158 of the RF Criminal Code characterized by the presence of aggravating circumstances. There is also a practice of exemption from criminal liability for robbery (Part 1 of Article 161): in 2019 there were 829 such cases. In general, over the past five years the legislator was actively expanding the conditions and grounds for exemption from criminal liability. Thus, for the specified period, besides court imposed fine, Article 76.1 "Exemption from criminal liability in connection with the compensation for the damage inflicted" received other amendments and supplements introduced by eight federal laws. Law enforcement practice has responded to these innovations with a large and increasing number of legal cases being dropped (exemption from criminal liability) on the grounds of compensation for losses or making amends for the damage inflicted by the crime. Thus, according to the Judicial Department of the Supreme Court of the Russian Federation, the number of dropped cases, excluding exemption from criminal prosecution due to the absence of the elements or event of the wrongful act, amounted to 90,911 or $39.7 \%$ of the total number of cases of those convicted of encroachment on property, which is significantly more than in $2018(90,911$ and 76,474$)$. The difference in the ratio of those exempted from criminal liability to the total number of convicted persons during the analyzed period of time is also noticeable: $39.7 \%$ and $30.9 \%$. This is against the background of a reduction in the total number of convicts in 2019 as compared to 2018: from 249,231 to 228,953 [6].

The analysis conducted in the field of application of penalties and exemption from criminal liability objectively raises the issue of the social effectiveness of the state's criminal enforcement policy related to committed crimes, including those in the field of property protection, understood as "effectiveness" reduced to the ability to influence something [5, p. 914]. In our research, effectiveness implies achieving the goals of criminal punishment in general, and a fine in particular.

The legal definition of purposes of punishment is given in Article 43 of the Criminal Code. These include restoring social justice, reforming a convicted person and preventing the commission of further crimes. The provisions 
of the analyzed article on the correction of the convicted person and prevention of crimes are generally definite; however, there is no such certainty regarding social justice as the goal of punishment. We think that controversial issues in this area of public relations should include the legally established conditions under which persons who have committed crimes, including crimes against property, can be exempted from criminal liability. For example, the liability of an individual who has the financial means to compensate for the material damage and other harm inflicted is virtually reduced only to the deprivation of these means. But those who do not have such means to be used for exemption from criminal liability face actual criminal punishment including incarceration and other negative consequences associated with a criminal record. Part 2 of Article 88 of the RF Criminal Code contains a very controversial position that conflicts with the principle of fault-based liability: it states that "a fine imposed upon a convicted juvenile may be recovered by decision of a court of law from his parents or other legal representatives thereof with their consent. A fine shall be imposed in the amount from one thousand to 50 thousand rubles or in the amount of the wage or salary, or any other income of the convicted minor, for a period of from two weeks to six months".
Thus, the research we have conducted makes it possible to draw the following generalizing conclusions.

The value of a fine in the system of criminal penalties, especially regarding all crimes against property, tends to increase significantly. This applies to a significant extent to court imposed fines that provide an opportunity of exemption from criminal liability, including cases of crimes with aggravating circumstances (Parts 2 and 3 of Article 158 of the RF Criminal Code).

Crimes against property should be considered as a threat not only to property, but also to human life and health (Article 162 of the RF Criminal Code), spiritual, moral and other values of an individual and society. In our opinion, this approach, should be used as a guide both in legislative and law enforcement practice, including cases of applying a court imposed fine.

The issues concerning the effectiveness of criminal penalties, including the imposition of a fine, are multifaceted. Besides the implementation of the goals of punishment, these issues include the creation of a consistent and effective legal framework, in the field of criminal policy as well; education of law-abiding citizens on this basis; ensuring the inevitability of punishment for any offense; a high level of professionalism and responsibility of persons involved in the implementation of protective norms, and so on.

\section{REFERENCES}

1. Bezverkhov A.G. Imushchestvennye prestupleniya: avtoreferat dissertatsii na soiskanie uchenoi stepeni doktora yuridicheskikh nauk [Property crimes: Doctor of Sciences (Law) dissertation abstract]. Izhevsk, 2002.42 p.

2. Bochkarev S.A. Ugolovno-pravovaya okhrana sobstvennosti: teoretiko-instrumental'nyi analiz: avtoreferat dissertatsii na soiskanie uchenoi stepeni kandidata yuridicheskikh nauk [Criminal-legal protection of property: theoretical and instrumental analysis: Candidate of Sciences (Law) dissertation abstract]. Moscow, 2010. 26 p.

3. Ershov V.V. Pravovoe $i$ individual'noe regulirovanie obshchestvennykh otnoshenii: monografiya [Legal and individual regulation of public relations: monograph]. Moscow: RGUP, 2018. 627 p.

4. Luneev V.V. Prestupnost' XX veka: mirovye, regional'nye i rossiiskie tendentsii [Crime of the twentieth century: world, regional and Russian trends]. Moscow: Volters Kluver, 2005. 912 p.

5. Ozhegov S.I., ShvedovaN.Yu. Tolkovyi slovar' russkogo yazyka: 80000 slov i frazeologicheskikh vyrazhenii [Explanatory dictionary of the Russian language: 80,000 words and phraseological expressions]. Moscow: Azbukovnik, 1999.944 p.

6. Otchet o chisle osuzhdennykh po vsem sostavam UK RF za 2018 i $2019 \mathrm{gg}$. [Report on the number of convicts under all parts of the Criminal Code of the Russian Federation for 2018 and 2019]. Available at: http://www.cdep.ru/index. php?id=79\&item=5259 (accessed April 12, 2020).

7. Sostoyanie prestupnosti v Rossii za yanvar' - oktyabr' $2018 \mathrm{~g}$. [Crime situation in Russia in January-October 2018]. Available at: https://genproc.gov.ru/upload/iblock/ddb/sbornik_10_2018.pdf (accessed April 12, 2020).

8. Khatuaev V.U., Shaimova E.S. Problems of the effectiveness of punishments in the works of Soviet scientists of the second half of the 20th century. In: Sudebnaya vlast' i formy ee realizatsii v Rossii: sbornik materialov Vserossiiskoi nauchnoprakticheskoi konferentsii [Judicial power and forms of its implementation in Russia: proceedings of an all-Russian scientific and practical conference]. Voronezh: Istoki: Tsentr. fil. Ros. akad. pravosudiya, 2011. Pp. 133-141. (In Russ.).

9. Chernikov V.V. Sovremennaya gosudarstvennaya sistema okhrany sobstvennosti v Rossii [Modern state system of property protection in Russia]. Moscow: Infra-M, 1995. 224 p.

10. Shul'ga A.V. Ob"ekt i predmet prestuplenii protiv sobstvennosti v usloviyakh rynochnykh otnoshenii i informatsionnogo obshchestva: monografiya[Object and subject of crimes against property in the conditions of market relations and information society: monograph]. Moscow: Yurlitinform, 2007. 376 p.

11. Sukharev A.Ya. (Ed.). Yuridicheskii entsiklopedicheskii slovar' [Encyclopedic dictionary of law]. Moscow: Sovetskaya entsiklopediya, 1987.528 p.

\section{INFORMATION ABOUT THE AUTHORS}

IRINA V. AZAROVA - Senior Lecturer of the Department of Civil Law and Economic Disciplines, Voronezh Institute of the Ministry of Internal Affairs of the Russian Federation, Voronezh, Russian Federation. ORCID: 0000-0003-3497-2126, e-mail: aziravlad@rambler.ru

IVAN V. DVORYANSKOV - Chief Researcher, Doctor of Sciences (Law), Professor, Research Institute of the Federal Penitentiary Service of Russia, Moscow, Russian Federation. ORCID: 0000-0003-0542-5254, e-mail: diw@yandex.ru 